\title{
Bibliographical Note
}

Although Lampman published just over one hundred poems during his lifetime and an additional thirty-nine appeared in the posthumous volume, Alcyone, his manuscripts contain over four hundred poems. Duncan Campbell Scott became literary ex ecutor after his death and, with the assistance of two friends, S.E. Dawson and William D. LeSeur, arranged for the publication of The Poems of Archibald Lampman.

This volume, containing two hundred and thirty-seven poems, was published in 1900 by George N. Morang and Company of Toronto and the first edition was soon exhausted as the result of a letter requesting subscriptions which was sent out on 1 June 1899 by the friends. Almost five thousand dollars were obtained for Lampman's family, acknowledged by Scott, Dawson, and LeSueur in a note of thanks on the final page of the edition.

The quality of some of the poems was questionable, as Scott acknowledged in his introduction to Lyrics of Earth: Sonnets and Ballads in 1925: 'In this book almost everything that he had written was included. The critical faculty was in suspension. The aim was to produce a book attractive from its bulk, and considering the prime object of the publication, that idea was laudable enough...' The letter seeking advance orders for the collected poems explained the purpose of the volume and contained an interesting tribute to Lampman:

Ottawa, lst June, 1899

Dear Sir or Madam:

You have no doubt heard of the death of Archibald Lampman for it was very widely noticed by the press, and the leading 
newspapers in all parts of Canada gave expression in their editorial columns to the prevailing feeling of regret and sympathy - of regret that the country has lost one in the very foremost rank of her men of letters, and sympathy for the young widow and children so sadly bereaved. Mr Lampman's position as a junior official in the Civil Service of the Dominion did not permit much provision to be made against his early death, and it is needless to dwell upon the trite observation that the pursuit of literature in Canada is not remunerative in a pecuniary sense. Nevertheless, the born poet is like a song bird and must utter his melody whether listened to or not. In reality, we all profit by every true poetic utterance, for it is through the works of poets and other literary men that the community gains its rank in the world of letters; and when they demonstrate abroad the ability of Canadians to wield with power the resources of their mother tongue, every Canadian shares the lustre of their labours and their triumph.

We have had, and we still have, writers who have brought to us from the motherland results of training acquired there, and of natural gifts, which are the outcome of different conditions. For these writers, and for their labours among us, we ought to be, and we are, sincerely grateful. But Archibald Lampman is one of our very own, born among us, trained in our schools, familiar with our ways, and intimate with every aspect of our skies, weeds and waters. The historic land of his forefathers he never saw with his outward eyes, but this, our own land, he knew by heart in all its marvellous variety of changing moods. In his poems he had described it with vivid and loving appreciation in every phase, from its resting time under the white coverlet faintly tinted with reflections of blue and rosy 
skies, through the brilliant outburst of spring and the sultry summer, to the dreamy autumn.

Lampman's reputation as a writer was not merely local. Many probably, who are not otherwise familiar with his work, have from time to time seen and admired his contributions to such magazines as The Atlantic Monthly, The Century, Scribner's, Harper's, Blackwood's etcetera. Out of a large number of notices of his work, which have appeared in English and American journals, a few are subjoined.

It is not possible now to do anything for him whom we have lost. In his life he was simple and unobtrusive, but his gentle presence and quiet voice will be only the more missed by his intimate friends. To borrow a poet's word on a like occasion:

He is a portion of the loveliness

Which once he made more lovely. He doth bear

His part, while the One Spirit's plastic stress

Sweeps through the dull, dense world.

We still, however, possess the poems which express his quiet, meditative soul; and it is open to us to express our appreciation of his work and testify our sympathy with those who have been deprived of his support, by adding to our libraries a copy of the memorial edition of his collected poems. The object of this letter is to explain what is being done for the production of such an edition, and to bespeak the interest of all cultivated readers.

There is now being prepared, and will be published for the sole benefit of the widow, a collected edition of Archibald Lampman's poems. It will be one volume of four hundred to five 
hundred pages, and will be printed in excellent style on good paper. The volume will be edited by the late poet's most intimate friend, Mr Duncan Campbell Scott and will contain a portrait of Lampman and also a short biographical sketch. It will include, in addition to the work which Mr Lampman had published in his lifetime, a careful selection from a quantity of unpublished work, all in fact, which there is reason to believe he would himself have eventually published. A facsimile of a sonnet in his own hand will also be included. The price of the volume has been fixed at $\$ 2.25$.

This somewhat unusual method of direct application has been adopted in order to secure to the widow the full and entire return without deduction or discount of any kind whatever. The undersigned are attending to this work solely as a tribute to the memory of a departed friend and in aid of his family. There are friends also concerned who wish to be nameless, but it is necessary that some names should appear as responsible for the undertaking. It will not be possible to employ canvassers to solicit subscriptions. Those who have taken the initiative in the matter feel confident that there are many who 'strictly meditate the thankless muse' who will assist in sending in subscribers' names and they believe that there are many men busily engaged in important undertakings and reaping the well-earned rewards of many remunerative callings, who have the love of letters at heart, and will not grudge the few moments necessary to fill up the enclosed form for copies, not only for themselves but for their friends.

In this hope we make our appeal, trusting that the response will be prompt and generous and that a lasting memorial may be established for one whose name, highly honoured as it is 
today, is destined, we believe, to greater honour in the future.

With great respect, we are,

Yours truly,

S.E. Dawson, Lit.D., F.R.S.C.

William D. LeSeur, B.A.

Duncan C. Scott, F.R.S.C.

Morang brought out a two-volume Holiday Edition in 1901 with the following note:

The universal attention which was aroused by the publication of the memorial edition of Archibald Lampman's poems was an indication of the esteem in which he was held as a poet and a man; and the large advance subscription sale for the work comprised residents in nearly every part of Canada and in places very distant from the somewhat small sphere in which the poet's life was spent. In placing before the public this second edition of the Poems, the publishers are obeying numerous and earnest requests, and they feel sure that the book will be prized by an ever-widening circle of appreciative and cultured readers.

Toronto, September, 1900.

This note was included in all later editions.

The Holiday Edition was succeeded by the third edition published by Morang in 1905. A fourth and final edition was published by the Musson Book Company Limited about 1915. All four editions contain identical texts. Variations in the four editions are minimal; for this reprint the first edition of 1900 has been reproduced. 
Scott edited several new editions of Lampman's poetry, and in 1925 the Musson Book Company published Lyrics of Earth: Sonnets and Ballads, which contains one hitherto unpublished poem, 'Impromptu,' and an evaluation by Scott of Lampman's work. In 1943, Scott and E.K. Brown edited At the Long Sault and Other New Poems, with a foreword by Scott and an introduction by Brown. The final collection of Lampman's poetry, Selected Poems, chosen by Scott, was published by the Ryerson Press in 1947. It contains no new work but is a judicious selection of the best of Lampman's poems. Scott wisely dropped the lengthy narrative poems, which add little to the poet's lustre and represent an outmoded literary convention. The measure of Lampman's art depends, therefore, upon two volumes, The Poems of Archibald Lampman and the later selection from his manuscripts, At the Long Sault and Other New Poems.

Lampman had a distressing habit of using titles more than once. The collected poems contain two poems entitled 'In November,' two named 'Song,' and two versions of 'The City.' In his 1925 selection, Scott retitled 'In November,' on page 117, 'Late November.' Lampman also published two versions of 'Dead Cities,' 'Passion,' 'Sleep,' 'Music,' 'Winter Evening,' and 'New Year's Eve,' as well as a third poem entitled 'Song.' These poems may be differentiated by the date on which each was written, given in Lampman's manuscripts and letters, by the first lines and, in some cases, by the form used. The notes below are offered as a guide to duplicate titles in The Poems of Archibald Lampman.

PAGE

40 Song

First line 'Songs that could span the earth.' Five stanzas of four lines (1886) 
48 A Song

First line ' $O$ night and sleep.' Five stanzas of six lines (1885)

117 In November

First line 'The hills and leafless forests slowly yield.' Sonnet (November 1887). Accepted title now 'Late November'

118 The City

First line 'Beyond the dusky cornfields, towards the west.'

Sonnet (1887)

158 In November

First line 'With loitering step and quiet eye.' Irregular; three stanzas of twenty-two, sixteen, and sixteen lines (November 1889)

215 The City

First line 'Canst thou not rest, 0 city.' Thirteen stanzas of four lines (1890) 